vexed questions of subsidies and economics, it appears that under the existing system hill farming is less efficient than its lowland counterpart, but there is no evidence that more is being paid to support agriculture in the uplands. Some confusion seems to exist regarding the purpose of the Government subsidy, whether the money is intended to be apportioned on a basis of efficiency, the amount and value of production or as a means of equalizing net farm incomes. From the present report, it appears that only under the first set of conditions is its object being achieved.

\section{Cultivation and Purification of Shellfish}

Two current publications from the Ministry of Agriculture, Fisheries and Food incorporate the results of recent researches on shellfish at the Ministry's laboratories at Burnham-on-Crouch and Conway. Dr. H. A. Cole's manual on "Oyster Cultivation in Britain" (pp. $45+23$ plates. London : H.M. Stationery Office, 1956. 5s. net) is primarily intended for those contemplating oyster-farming, but could be read with advantage by all concerned with the industry. The first parts describe the areas suitable for oyster cultivation, pollution problems and the legal aspects. There is then a section on work throughout the season, including relaying, collection of spat, control of pests, and marketing, while other sections deal with making and reclaiming beds and the purchase of oysters for relaying. Many potential oyster-beds in Britain are being neglected; it is hoped that this booklet will provide a stimulus to the industry.

It is well known that mussels and other shellfish can be freed from sewage pollution by making use of the animals' own feeding methods to remove harmful bacteria. Until now, such treatment has involved large-scale processing and a permanent staff, and it is gratifying to learn that Mr. N. Reynolds has devised a simplified system of purification that can be operated by the fishermen themselves (Ministry of Agriculture, Fisheries and Food, Fish. Invest., Ser. 2, 20, No. 8. London: H.M. Stationery Office, 1956 ; 5s. net). The washed mussels are given three 24-hr. baths in shallow tanks of sea-water filled on the incoming tide, hosed and packed in clean sacks. The bacteriological results have been comparable to those of the more expensive method.

\section{Viruses in Wild Plants}

THE information available on the general distribution and frequency pattern of viruses in weeds and wild species, some of which may become-important in crop pathology, is still very scanty. In a study of virus in wild plants, W. D. MacClement and M. G. Richards (Canadian J. Bot., 34, 5, 793 ; 1956) have found that there are very few species which are free from possible virus infection. In comparison with this, most flowering plants growing under the surface of open water show a low but significant amount of virus. The indicated level of virus infection varies throughout each summer and from one summer to the next, but is often surprisingly high. 'The total annual infection under the conditions employed was approximately 10 per cent of the sample population. The amount of infection in all plants varies with species and location from 0 to 50 per cent. Total virus infection appears to be related to the growthrates of plants. 'I'he types of virus included several common to commercial crop plants, many unidentified mixtures, and some distinetly new viruses.

\section{Japanese Forestry Research}

IN Report No. 3 of the Government Forest Experiment Station (Meguro, Tokyo, 1953) the forest soil survey of an area in the Amaji Mountain Range was dealt with (see Nature, 175, 672; 1955), and now Reports 6 and 7 continue those soil surveys, both with an extra brochure of beautifully executed soil maps (Tokyo, 1956). The unit dealt with in Report No. 6 is situated in the north-western part of the Gifu Prefecture in Central Honshu, and the investigations carried out are on the same lines of Report No. 3. In Report No. 7 each of the seven management units in the basin of the River Yonoshiro, Akita Prefecture, were surveyed, and the relationship between the soil properties and forest growth is discussed. The area is mostly hilly. Tertiary green tuff, sandstone, shale and conglomerato occupy 65 per cent of the area, and liparite, andesite and granite the rest. Annual mean temperature, precipitation, humidity and prevailing wind direction received attention. Recommendations are made on the regeneration of the forests either by artificial means, spruce being considered, or by natural regeneration where possible. The Japanese Forest. Service has been very thorough in these valuable soil surveys, which are so essential when large areas are either to be afforested or rehabilitated after destructive utilization. The maps which accompany the reports are of high artistic value.

\section{An Inexpensive Vacuum Pump}

IN the Museums Journal, November 1956, Mr. E. Martin Burgess, of the Department of Egyptology. Eniversity College, London, describes a method for constructing a cheap and simple pump for evacuating impregnating chambers in remote places where there is no source of power. Recently, it was proposed that the Nimrud ivories should be impregnated with polyvinyl acetate in vacuum jars at Nimrud rather than bring them back to England for the operation, for however carefully such objects were packed, damage in transit would be almost certain to occur. Naturally, no water vacuum pump could be used at Nimrud. It was therefore necessary to devise a cheap, simple, light-weight pump which could be made easily. This was accomplished by adapting a car-tyre pump to operate in reverse, replacing the inner tube valve on the car wheel by a one-way valve open only on the suction stroke. Working details with diagrams are given in the paper quoted, and the apparatus would doubtless be useful in many instances where a water supply of sufficient pressure is not available.

\section{Direction of Seismological Fault Movement in New} Zealand

THE question of the direction of fault movement in New Zealand has been considered by G. A. Eiby from an examination of the direction of the initial movement on seismograms from Karapiro, Wellington, Cobb River and Kaimata (Seism. Obs. Bull., No. $S-101$; 1955). The method used is largely that developed by B. Gutenberg in southern California (Bull. Seism. Soc. Amer., 31 (4), 263; 1941). In this method earthquakes are considered as a group when the faults in the region have a reasonably uniform alignment. Most of the active faults in New Zealand strike north-east. Maps have therefore been drawn for each of the four seismological stations mentioned above, and each shows the epicentres of all well-recorded earthquakes between July 1, 1951, 